\title{
Interior Design of Basketball Center in Surakarta with Pop Art Theme
}

\author{
Marinda Humarahma a, ${ }^{a,{ }^{*}}$, IF.Bambang Sulistyono ${ }^{b, 2}$ \\ ${ }^{a}$ Interior Design Study Program, Faculty of Art and Design, Sebelas Maret University, Surakarta, Indonesia. \\ 1 marinda.humarahma@gmail.com *; ${ }^{2}$ ifbambang@staff.uns.ac.id; \\ * Corresponding Author
}

Received 25 October 2021; accepted 28 November 2021; published 3 December 2021

\section{ABSTRACT}

Basketball Center Interior Design in Surakarta with Pop Art Theme aims to (1) Create an interior design of sports hall that is able to attract the attention of the public in exercising and maintaining health. (2) Create a basketball center that can increase the passion of exercising while practicing or competing through the atmosphere. The methods used in this study are programming that includes library studies, surveys, interviews. Then data analysis, idea development, and design methods. From this analysis can be summed up several things: (1) Basketball center interior design as a physical fitness center and a container of sports activities especially basketball sports designed to influence the psychology of players. (2) Shapes, colors and materials applied according to the theme namely pop art on all interior elements. (3) The atmosphere of the room that is raised is a cozy, cheerful, unique, interesting, free, and limitless atmosphere

\section{KEYWORDS}

Basketball Center

Pop Art

Sports

Design

Interior

This is an openaccess article under the CC-BY-SA license

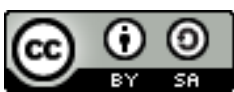

\section{Introduction.}

The sport of basketball in 2015 until now has shown a very rapid increase, with the rise of associations and matches and a large number of spectators in a match, both young and old. According to a report released by the National Basketball League or NBL Indonesia, this year the NBL attracted a total of 151,369 spectators or grew about 50 percent from the previous season (nblindonesia, 2012). The data was submitted by the league manager, PT Detection Basket Lintas Indonesia, after the end of the Championship Series in Yogyakarta. In the previous year's data, namely in the inaugural season of NBL Indonesia in 2011-2012, the total audience was recorded at 103,414 people. Basketball is one of the team sports that is experiencing fairly rapid development, this is because this type of sport is not only a sport for developing achievement, but also sports based on education and recreation. This illustrates that the game of basketball is a very popular sport and favored by the people of Indonesia, especially the city of Surakarta.

Sport and health have a direct link to the economy. Rusli Lutan, said that in Australia, health and sports have taken root. Increasing public participation in sports by $5 \%$ would reduce health care budgets by 439 million dollars (Hadjarati, 2009). While an investment of 1 dollar for sports activities will save health care costs of 3.2 dollars. This will certainly affect reducing the number of people who are sick and can create a physically, mentally, and physically healthy society. Then from the social aspect, it can be observed that sport is a unique activity that can strengthen social integration. From the enormous benefits of sport, from the structure of existing facilities and infrastructure, Indonesia is still very weak.

Sport is an activity carried out to improve health, and as a recreational activity that can improve achievement. In Indonesia, sport is a popular activity that effectively introduces Indonesia to the international arena through world-class championships. Certain sports that have become Indonesia's mainstay in the international arena are such as badminton, pencak silat, aquatics, karate, tennis, and athletics, so the government must continue to strive to advance all supporting facilities for the improvement of sports in Indonesia. 
However, most of the sports halls available today still do not attach importance to several important aspects that can not be realized that can affect one's psychology, namely through colors that can increase one's spirit and color can affect one's emotions and body health. Moods can also change when they see certain colors, as well as when players or athletes see these colors, it is believed that they can increase their enthusiasm for exercising.

In connection with this, what needs to be done is to design a basketball arena that is tailored to the functions and purposes used without compromising the main purpose of the sports arena by designing a sports center that can affect a person's mental, behavior, and mood.

\section{Method}

The design process for the interior design project of the Basketball Center in Surakarta is carried out by referring to Figure 1 .

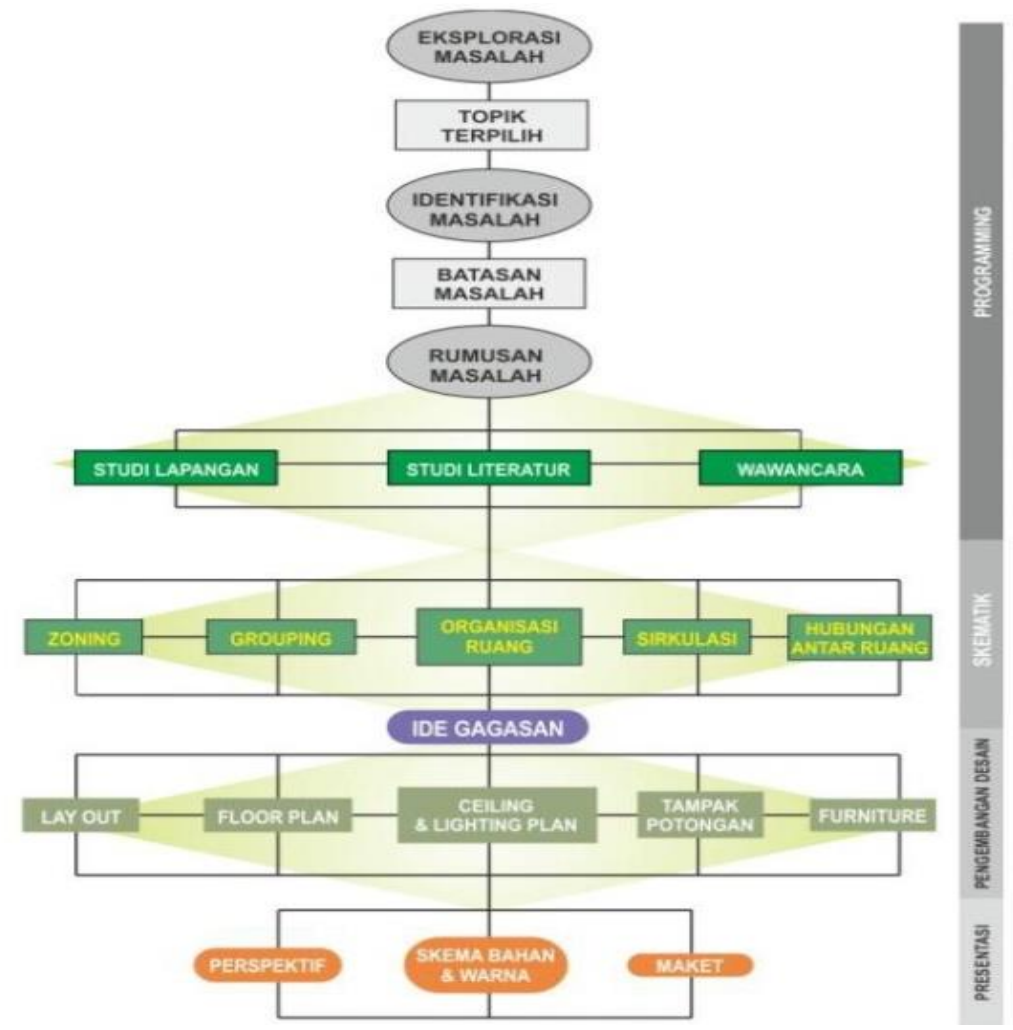

Fig. 1. Design Process Schematic

The design methodology applied to Interior Design was compiled based on references by Ballast (1992). This process is developed as shown in schematic 1.1.

- At the programming stage, a general design concept is developed based on the stated goals and user needs. After the project topic has been determined, the data collection steps are carried out through:

- Literature review.

The author collects the necessary information by conducting a literature study, namely by looking for information through related books and journals.

- Survey.

Conducted visits to several sports buildings in big cities to obtain data and information regarding their condition and design.

- Interview.

The author conducted a question and answer orally to the person in charge of the manager of the sports building.

- Documentation.

Documentation is done by taking pictures with a digital camera and sketching in spaces that are not allowed to be immortalized with equipment. 
- The data that has been obtained is then analyzed to prepare a schematic concept consisting of zoning, grouping, room size, space organization, circulation flow, patterns of relationships between spaces.

- Idea Development.

This Basketball Center interior project was developed with a pop art theme. Design development in this project was carried out using freehand sketch media and a computer with the Sketchup application. The steps taken are as follows: (a) sketch interior or furniture with pencil and paper (Olofsson \& Sjolen, 2006); (b) transferring images to a computer with the Sketch up application; (c) Make variations of the shape and size of room or furniture components with sketch up an application in several alternatives (Widyokusumo, 2013); (d) select and apply the material.

\section{Results and Discussion}

\subsection{Programming.}

The interior design of the Basketball Center in Surakarta is a public building devoted to accommodating a sporting activity. This Basketball Center also provides information to the people of Surakarta and its surroundings about the importance of sports activities and maintaining health and fitness, (Ferkel et al., 2014). The word design comes from the word design (Italian) which means image. According to the Association of Indonesian Design Experts, as stated in its articles of association, that design is a problem-solving (Chen et al., 2021), (Chou \& Truong, 2020), tool that voices the culture of its era (Widayat, 2011). The definition of design is everything related to concept generation, data analysis, project planning, drawing/rendering, cost calculation, prototyping, frame testing, and test riding. Design is a physical translation of the social, economic, and living aspects of human life, and is a reflection of the culture of the era. Design is a tangible manifestation of culture (Minguez Garcia, 2021), design is a product of values that apply at a certain time (Sachari, 2008).

The interior is the inner part of any building and however (Knarud et al., 2021), the shape of the building is limited by floors, walls, and ceilings (Suptandar, 1982). Basketball, game played between two teams of five players each on a rectangular court, usually indoors. Each team tries to score by tossing the ball through the opponent's goal, an elevated horizontal hoop and net called a basket (Anonim, n.d.-a). The point around which a circle or sphere is described broadly: a point that is related to a geometrical figure in such a way that for any point on the figure there is another point on the figure such that a straight line joining the two points is bisected by the original point called also a center of symmetry (Anonim, n.d.-b). The city of Surakarta is an autonomous region with the status of a City under the Province of Central Java, Indonesia, with a population of 503:421 inhabitants (2010) and a density of $13,636 / \mathrm{km} 2$. The city with an area of $44 \mathrm{~km} 2$ is bordered by Karanganyar Regency and Boyolali Regency to the north. Karanganyar Regency and Sukoharjo Regency in the east and west, and Sukoharjo Regency in the south.

According to (Liang, 1976), broadly speaking, the theme is the main idea in question in the work of art. The main idea of a work of art can be understood or recognized through the selection of the subject matter and the title of the work. The subject matter can be related to aesthetic values or life values, namely in the form of natural objects, material objects, ambience, or events that are metaphorical or allegorical. Pop Art, according to the Oxford Dictionary, Pop Art is an abbreviation of "Popular Art" is an art based on modern popular culture (Dodds \& Funnell, 2020), and mass media, especially as a critical or ironic commentary on traditional art.

\subsubsection{Assumed Location}

The location of this building is located on Jalan Abiyoso No. 21, Sriwedari, Kec. Laweyan, Surakarta City, Central Java 57141. The location is an upper-middle-class area and is in the vicinity of a shopping center. The selected location is appropriate and follows Peraturan Daerab Kota Surakarta Nomor 1 Tabun 2012 Tentang Rencana Tata Ruang Wilayab Kota Surakarta Tabun 2011-2031. With the selection of the Laweyan sub-district as the location, the Basketball Center will be built entered as a function of tourism and sports areas. Operating system, the Basketball Center in Surakarta has the following operational requirements: (a) Monday, 24 hours; (b) Tuesday 24 hours; (c) wednesday 24 hours; (d) Thursday 24 hours; (e) friday 24 hours; (f) saturday 24 hours; (g) sunday 24 hours. The institutional status of the Basketball Center in Surakarta is managed by the private sector so that management and implementation orientation are fully borne by the private sector under the auspices of the Bhinneka Solo Basketball Association. 


\subsubsection{Space Forming Elements}

- Floor.

In the application of the floor of the room using several basic considerations such as easy to maintain, the floor emphasizes the boundaries of the existing space by applying different floor levels or differences in floor material, floors with safe and non-slippery materials. Such as the use of vinyl in the field and ceramic or granite floors in other rooms.

- Wall.

For the application of wall elements using basic considerations, namely the wall is an insulator against solar radiation to maintain the temperature in the room, the wall can reduce noise from inside and outside the room, the wall functions as a barrier that separates one room from another, the wall/wall wallpaper adjusts design theme and wall/wallpaper using colors that match the concept and theme of this Basketball Center project design.

- Ceiling.

At the ceiling using basic considerations such as no longer needing heat insulation or noise. The twin-wall air cavity construction doubles up to retain heat and is also soundproof when it rains. Strong construction, with the ability to withstand loads up to $150 \mathrm{~kg}$. Serves to emphasize the function of the space below and the selection of colors and ceiling shapes that match the theme.

\subsubsection{Interior System}

- Lighting.

Lighting has a very important role in the interior design of a space. There are 2 types of lighting in the playing area, namely natural lighting and artificial lighting. Natural lighting is obtained from sunlight that penetrates the glass/tempered glass walls and several windows. Then for natural lighting use spotlights because the ceiling is far from the floor as general lighting and some additional lights such as downlight and indirect lamp as additional accents.

- Ventilation.

The ventilation system in the Basketball Center in Surakarta has two systems, namely natural and artificial ventilation. Natural ventilation is obtained from good openings of doors, windows, and ventilation. Natural ventilation is needed to allow for the entry of fresh air. For artificial ventilation, use AC Split 2 PK Panasonic CS-PN18RKP (CU-PN18RKP), ceiling AC and exhaust.

- Security.

Security systems are important for the safety and comfort of visitors. At the Basketball Center, there are several security devices such as CCTV, fire detectors, fire extinguishers, and sprinklers at several points.

\subsubsection{Space Organization System}

Considerations to get a form of spatial organization that is by the function of the Basketball Center in Surakarta, the spatial organization must meet the following criteria (a) The grouping of spaces according to the grouping of user activities (see on Figure 3); (b) Sufficient level of space efficiency; (c) Directional circulation between rooms.

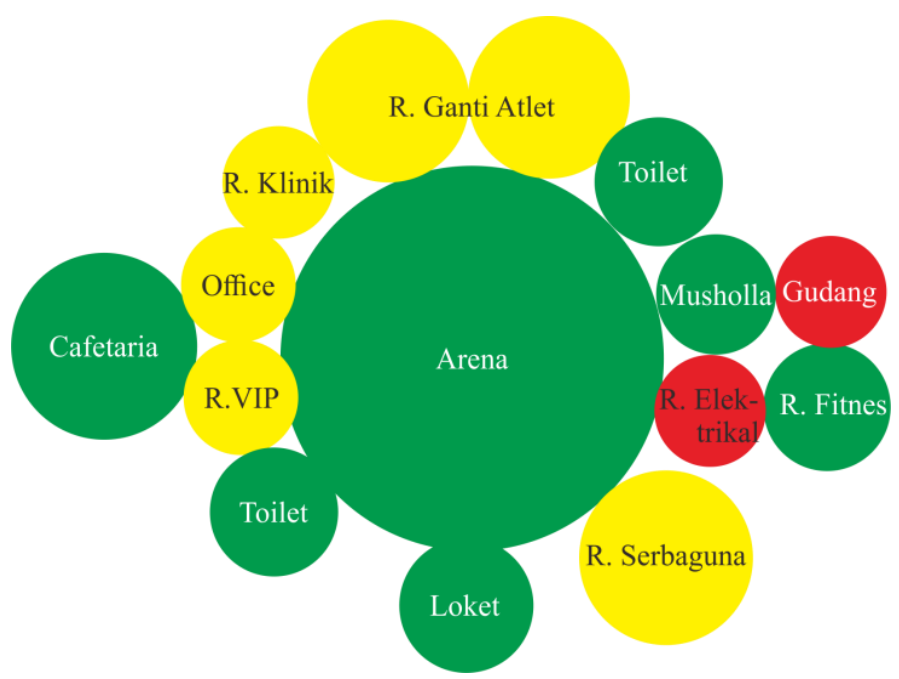

Fig. 2. Zoning dan Grouping 


\subsection{Concept.}

The design and design of the Basketball Center in Surakarta is a new design project that was established in the middle of the city of Surakarta. Basketball is a team sport that is experiencing fairly rapid development, this is because this type of sport is not only an achievement-building sport but also a sport-based sport. education and recreation. This illustrates that the game of basketball is a very popular sport and favored by the people of Indonesia, especially the city of Surakarta. This will certainly affect reducing the number of people who are sick and can create a physically, mentally, and physically healthy society. Because of the high interest in this sport, we want to design a building that maximizes the function of the building by influencing the psychology of players or anyone who visits to be more enthusiastic and enthusiastic about exercising. Basketball sports arenas tend to be colorfully designed with white lines, as well as other elements in basketball that have bright colors. This turned out to unwittingly create a more interesting match atmosphere. The designer took the pop art theme in this project, aiming to give new color and life to the area as well as arouse the community's desire to come together through sports activities.

The design and design of the Basketball Center in Surakarta is a design project for the Basketball Center in Surakarta using a pop art theme, which focuses on an unusual, expressive, and colorful appearance. Pop art is an art movement that emerged in England in the mid-1950s period, in the early days of postmodern art. Not long ago, the Pop art trend also appeared in the United States. The application of the pop art theme in the room will give an artistic, bold, and colorful impression. Reflecting the urban style youth who are cheerful and very contemporary. This place was created to provide a different atmosphere as an informative and educational recreational facility so that it can increase the knowledge and interest of basketball fans themselves. In addition, the existence of this facility is expected to increase a sense of appreciation for the sport of basketball itself. The ambiance to be displayed is an artistic, bold, unique, and cheerful atmosphere (Sumarno \& Indarto, 2016). This ambience is created by the application of various prominent colors on the walls, ceiling, floor, and furniture throughout the room. Materials and materials for all interior elements including furniture must be considered because the function of the building is to exercise, so use a floor with a non-hard, nonslip material that is safe, such as vinyl, parquet, and carpet floors. The ambiance of the space that is raised is the dominance of bold and contrasting color schemes such as blue, yellow, red, and orange. Spatial planning at the Basketball Center uses structuring considerations based on room zoning, where the public space is placed in front of the entrance to the center of the building to facilitate access and service for visitors and the semi-private space is inside after the public space with an open space concept so that the semi-private area can still be seen. The private room is inside and at the end with a dividing wall so that the room is more private so that visitors are more comfortable. The spatial arrangement is also determined by the circulation system and the sequence of activities for both visitors and staff so that the arrangement of the space can be organized. See on figure 5.

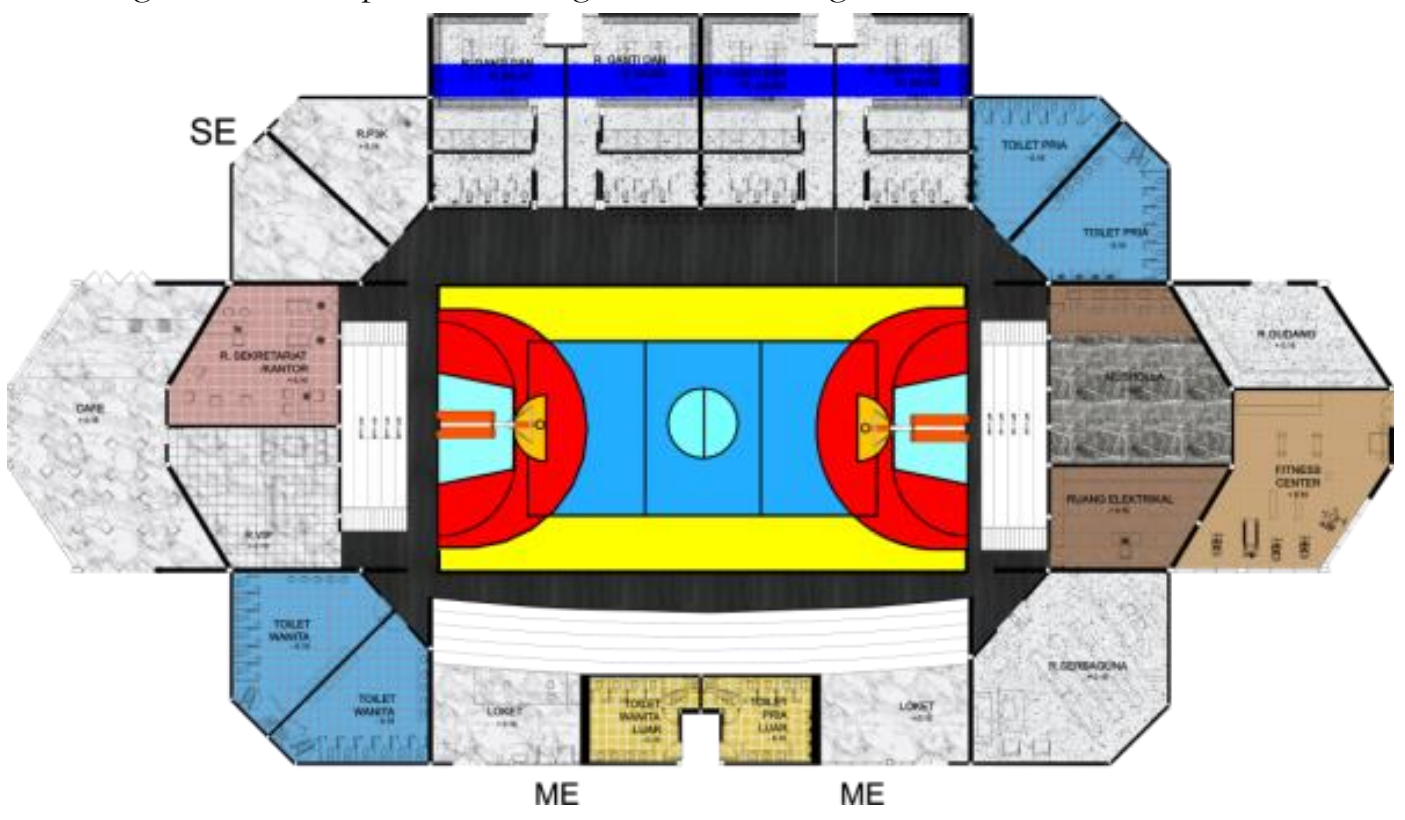

Fig. 3. Layout, Basketball Center in Surakarta. 


\subsubsection{Shapes, Colors and Materials.}

- Shape.

The form that will be displayed is a form that is following the character of the pop art style, namely breaking down the boundaries of art and being freer to determine the existing form. Sometimes it is sharp, dashing, sturdy or it can be curved that repeats itself to create its uniqueness.

- Color.

The colors that will be applied to the interior of the Basketball Center in Surakarta are dominated by bright blues, yellows, bright greens, and bright reds. Meanwhile, in work areas such as the secretariat room, neutral colors are used, but there is still a pop art theme, even if it's a little. See on figure 6.

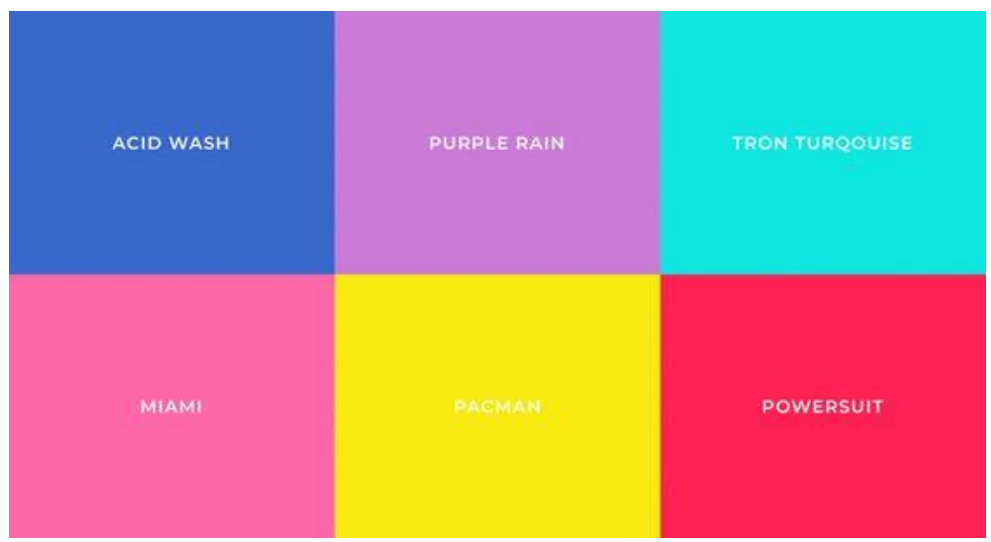

Fig. 4. Pop Art Pallete (Brochu, n.d.)

Fig. 5.

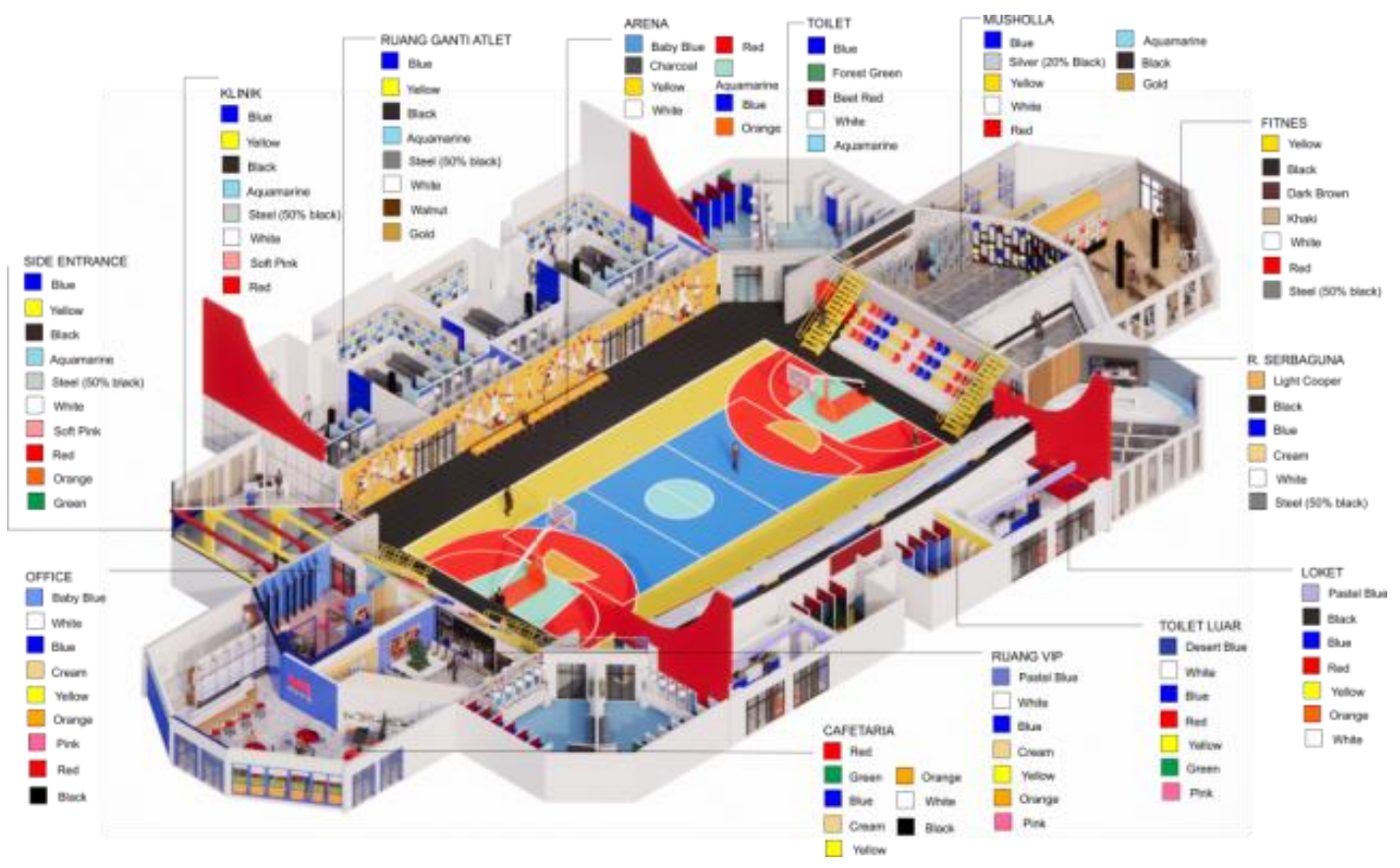

Fig. 6. Basketball Center Color Scheme in Surakarta

- Material.

The dominating materials for the interior of the Basketball Center in Surakarta are granite and marble which aim to give the impression of luxury, glamor, and high self-confidence. The attractive concept can be applied to the use of iron and stainless steel which have a glossy surface texture to give the impression of a lively and modern space. The use of wood that has as well as wood can be arranged to form a pattern. The use of acrylic glass gives a transparent impression 
so that the room has the impression of open space, without any obstacles and the circulation of the room becomes fast.

\subsubsection{Interior System}

- Lighting.

Lighting has a very important role in the interior design of a space. There are 2 types of lighting in the playing area, namely natural lighting and artificial lighting. Natural lighting is obtained from sunlight that penetrates the glass/tempered glass walls and several windows. Then for natural lighting use spotlights because the ceiling is far from the floor as general lighting and some additional lights such as downlight and indirect lamp as additional accents.

- Ventilation.

The air conditioning system in the Basketball Center has two systems, namely natural and artificial ventilation. Natural ventilation is obtained from the openings of both doors, windows, and ventilation. Natural ventilation is needed to allow for the entry of fresh air. For artificial ventilation, use Cassette AC, split AC, standing floor AC and exhaust.

- Acoustic.

The sports building with a fairly long span and the use of zinc alum metal roof coverings cause noise in the interior, but this can be anticipated by the use of Polyutherene in the form of absorber material mounted on the ceiling with a thickness of ", 1" or 3".

- Security.

Security systems are important for the safety and comfort of visitors. At this Basketball Center, there are several security devices such as CCTV, fire detectors, fire extinguishers, and sprinklers at several points.

\subsection{Facility}

\subsubsection{Counter}

The counter is the first focal point for visitors. This area serves to serve visitors for match tickets. Counter, as one of the facilities in public space, becomes a part of the object's identity (Chaemsaithong, 2021). Counter also reflects the ambience of the space. See on figure 8.

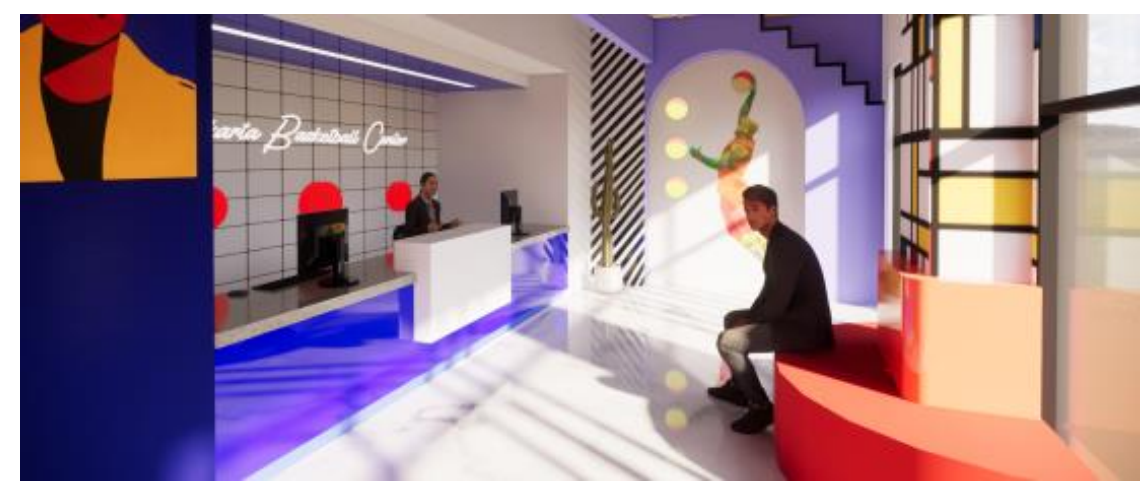

Fig. 7. Counter

\subsubsection{Arena.}

The arena is a room that is used to compete or practice several sports, but this project is devoted to basketball. This room is located in the middle of the building and is the main room of the building. Usually also called the arena. See on figure 9. 


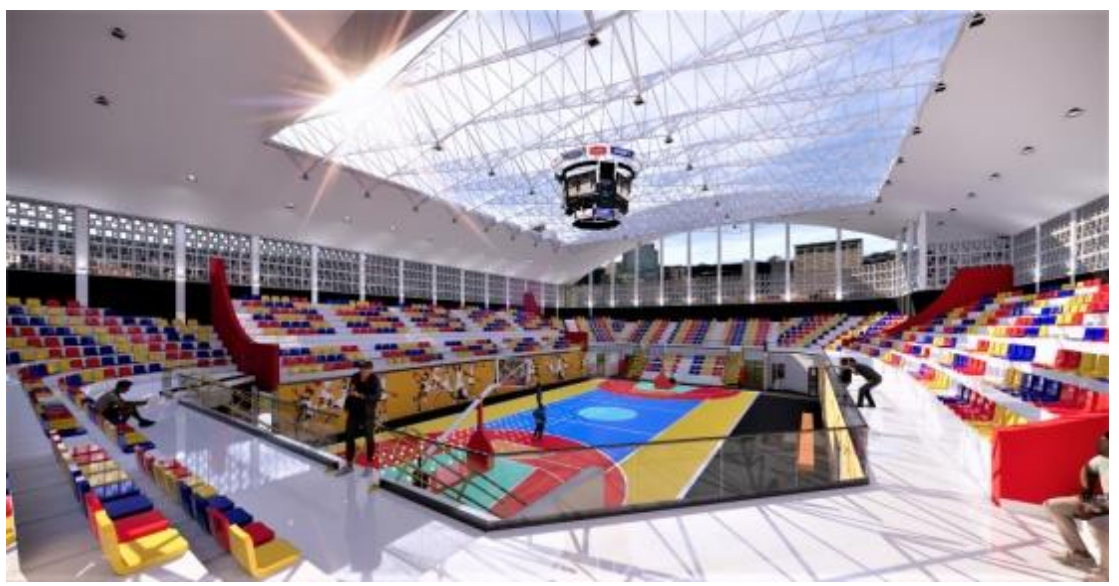

Fig. 8. Arena

\subsubsection{Office.}

Office or secretariat room as a place for staff and chiefs of staff to carry out administrative and secretarial activities needed in the management of the Basketball Center building. See on figure 10

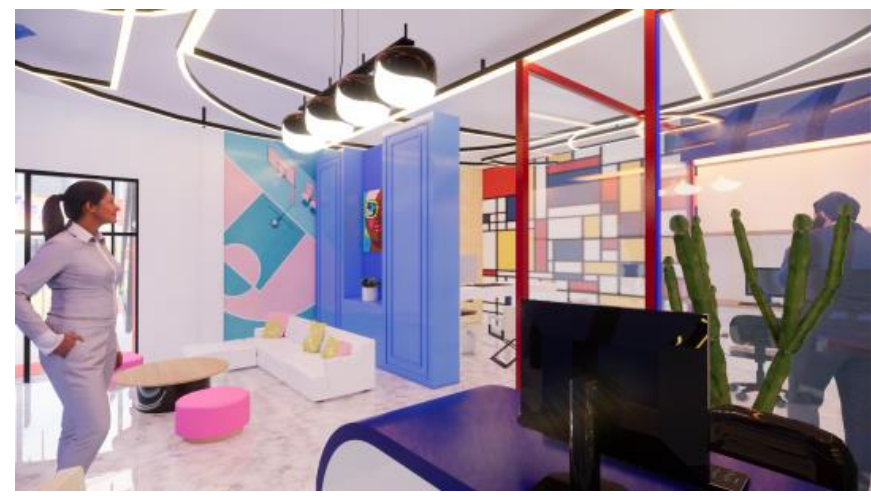

Fig. 9. Office (Source: Author)

\subsubsection{Musholla.}

The prayer room is a room that is devoted to facilitating Muslim worship activities (Shadrina, 2018). The prayer room (known as Musholla) is a room to facilitate Muslim worship activities (Shadrina, 2018). The existence of a prayer room is one of the important facilities for public spaces (Febrianti \& Syaodih, 2019). The prayer room for public spaces can even support the optimization of the basketball center as an effort to control and manage both emotions and fatigue (both physical and psychological). Even though the prayer room is a place of worship in the design, it is also presented with a touch of pop art to blend with other spaces. Another important think is the mark of Qibla direction in the prayer room which must be correct and precise by following certain rules (Budiwati, 2018). The prayer room is a room that is dedicated to facilitating Muslim worship activities that cannot be left behind. See figure 11.

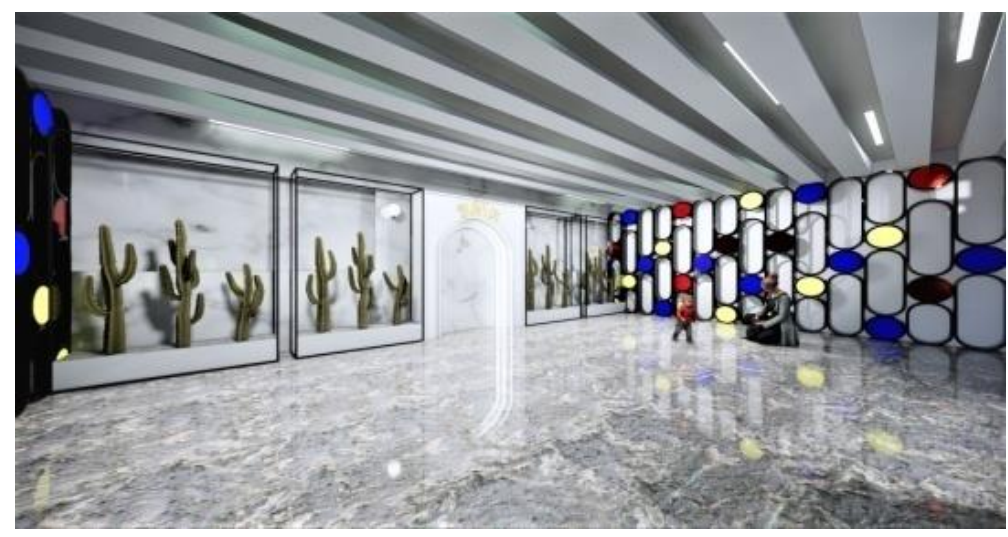

Fig. 10. Musholla (Source: Musholla). 


\subsubsection{Cafetaria}

The cafeteria is designed as a supporting room for a small restaurant that sells food, bread, cake, coffee, and tea so that basketball center visitors can buy the nearest food and drink. The cafeteria is designed as a supporting room for a small restaurant that sells food, bread, cake, coffee, and tea so that basketball center visitors can buy the nearest food and drink (Boniface, 2017),. See on figur 12

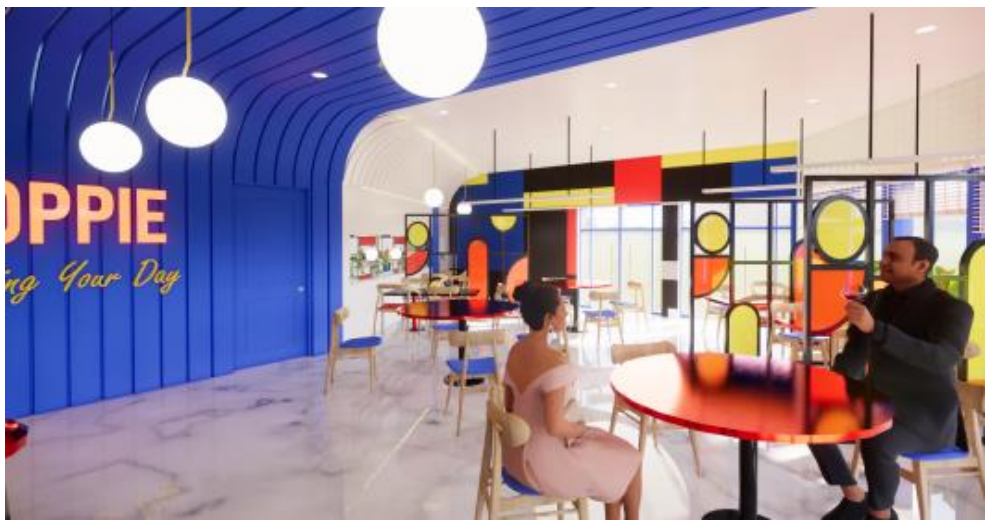

Fig. 11. Cafetaria (Source: Author)

\subsubsection{VIP Room}

The VIP room according to its acronym is a very important person, therefore this room is prepared to facilitate important people who are invited during the match. A luxuriously designed room for officials, chancellors, mayors, or public figures. See on figur 13

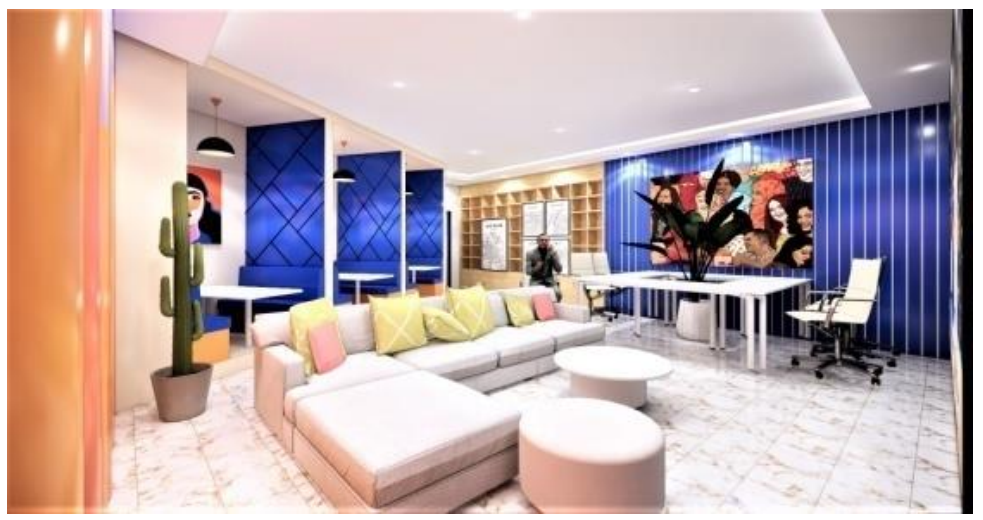

Fig. 12. VIP Room (Source: Author)

\subsubsection{Fitness Room}

The fitness room is very important as one of the fitness service facilities in this project. Store and provide sports equipment or physical exercise as well as complete with a mirror to monitor and maintain correct posture when exercising (Gois et al., 2020). See on figur 18.

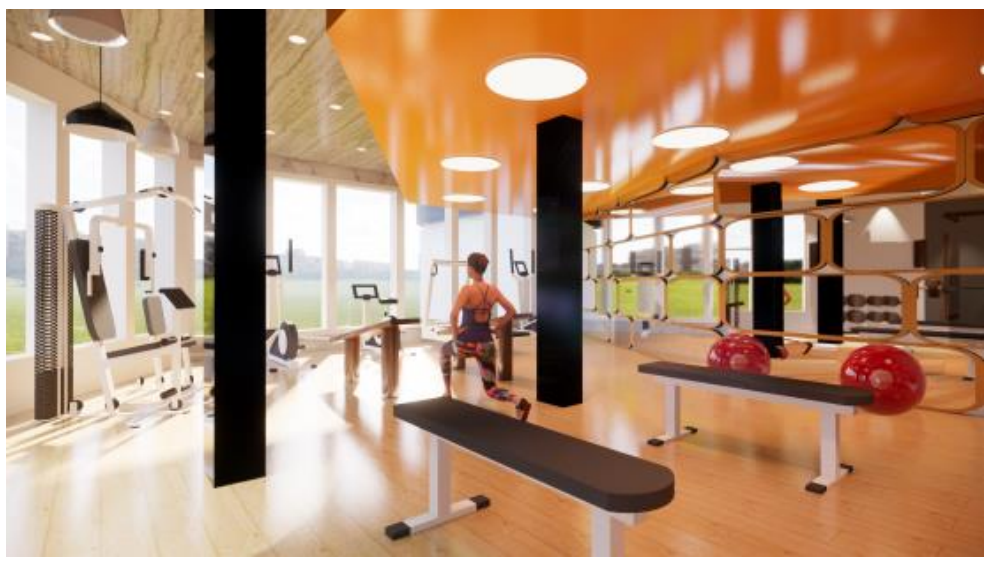

Fig. 13. Fitness Room (Source: Author) 


\section{Conclusion.}

Interior elements refer to the function of the user's needs for space, security, and comfort. The shapes, colors, and materials applied are following the theme, namely pop art on all interior elements and a little touch of modern interior design. The project location is in the upper-middle-class area and is located between shopping centers so that it is easy to reach. The atmosphere of the space that is raised is a comfortable, cheerful, unique, interesting, free, and limitless atmosphere. Materials and materials using materials that give an attractive impression can be applied to the use of iron and stainless steel which have a glossy surface texture to give the impression of a lively space.

\section{References}

Anonim. (n.d.-a). basketball. Britanica.Com.

Anonim. (n.d.-b). Centre. Merriam Webster Dictionary. https://www.merriam-webster.com/dictionary/center

Boniface, P. (2017). Tasting tourism: Travelling for food and drink. Routledge.

Brochu, E. (n.d.). Easter Coloring Pages, 40 Printable Easter Coloring Pages for Kids, Boys, Girls, Teens, Easter Egg Hunt, Rabbit/Bunny, Easter Party Activity.

Chen, T.-L., Chen, J. C., Huang, C.-F., \& Chang, P.-C. (2021). Solving the layout design problem by simulationoptimization approach-A case study on a sortation conveyor system. Simulation Modelling Practice and Theory, 106, 102192. https://doi.org/10.1016/j.simpat.2020.102192

Chou, J.-S., \& Truong, D.-N. (2020). Multiobjective optimization inspired by behavior of jellyfish for solving structural design problems. Chaos, Solitons \& Fractals, 135, 109738. https://doi.org/10.1016/j.chaos.2020.109738

Dodds, K., \& Funnell, L. (2020). Popular Culture. In International Encyclopedia of Human Geography (pp. 223-228). Elsevier. https://doi.org/10.1016/B978-0-08-102295-5.10854-6

Dong, X., Wu, Y., Chen, X., Li, H., Cao, B., Zhang, X., Yan, X., Li, Z., Long, Y., \& Li, X. (2021). Effect of thermal, acoustic, and lighting environment in underground space on human comfort and work efficiency: A review. Science of The Total Environment, 786, 147537. https://doi.org/10.1016/j.scitotenv.2021.147537

Ferkel, R. C., Judge, L. W., Stodden, D. F., \& Griffin, K. (2014). Importance of health-related fitness knowledge to increasing physical activity and physical fitness. Physical Educator, 71(2), 218.

Gois, M. de O., Simões, R. P., Porta, A., Kunz, V. C., Pastre, C. M., \& Catai, A. M. (2020). Cardiovascular responses to low-intensity isometric handgrip exercise in coronary artery disease: effects of posture. Brazilian Journal of Physical Therapy, 24(5), 449-457. https://doi.org/10.1016/j.bjpt.2019.07.010

Hadjarati, H. (2009). Memberdayakan olah raga nasional. Jurnal Pelangi Ilmu, 2(5).

Knarud, J. I., Geving, S., \& Kvande, T. (2021). Moisture performance of interior insulated brick wall segments subjected to wetting and drying - A laboratory investigation. Building and Environment, 188, 107488. https://doi.org/10.1016/j.buildenv.2020.107488

Liang, G. (1976). Garis Besar Estetika (Filsafat Keindahan). Yogyakarta: Pusat IImu Berguna.

Minguez Garcia, B. (2021). Integrating culture in post-crisis urban recovery: Reflections on the power of cultural heritage to deal with crisis. International Journal of Disaster Risk Reduction, 60, 102277. https://doi.org/10.1016/j.jjdrr.2021.102277

nblindonesia. (2012). Penonton NBL Tumbuh 50 PersenNo Title. PT. DBL Indonesia.

Olofsson, E., \& Sjolen, K. (2006). Design Sketching.pdf (2nd ed.). KEEOS Design Book.

Sachari, A. (2008). Metode Penelitian Budaya Rupa. Erlangga.

Shadrina, R. (2018). Kontestasi Politik Ruang (Studi Atas keberadaan Mushola Khusus Perempuan di Kauman).

Sumarno, \& Indarto. (2016). Implementasi Prinsip Quadrow Helix dalam Rancang Bangun Show room di Sentra Industri Kerajinan Rotan Sukoharjo.

Suptandar, J. P. (1982). Perancangan Tata Ruang Dalam (Interior Design). Penerbit PT Djambatan.

Widyokusumo, L. (2013). Fungsi Garis pada Desain dan Sketsa. Humaniora, 4(1), 339-347. 